\title{
Comparative study of oxidative stress in type 2 diabetes mellitus with in vitro oxidative stress using ferrous ascorbate as pro-oxidant
}

\author{
Asfia Afreen ${ }^{1, *}$, Dinesh Javarappa ${ }^{2}$, Itagappa $\mathbf{M}^{3}$ \\ ${ }^{1}$ Assistant Professor, ${ }^{2}$ Professor, ${ }^{3}$ Professor and Head, Dept. of Biochemistry, Basaveshwara Medical College Hospital and \\ Research Centre, Chitradurga, Karnataka, India
}

*Corresponding Author: Asfia Afreen

Email: murtuza4@gmail.com

Received: $7^{\text {th }}$ June, 2018

Accepted: $10^{\text {th }}$ July, 2018

\begin{abstract}
Diabetes mellitus is a chronic endocrine disorder associated with a multitude of microvascular and macrovascular complications. The imbalance between the productions of free radicals plays a prominent role in the development of these complications. Different markers of oxidative stress on erythrocyte membrane like Malondialdehyde (MDA), Protein carbonyl, Protein thiols and protein content of the membrane show variations which can be estimated to know the effect of oxidative stress. Similar effect is seen on erythrocyte membranes when these are subjected to proxidants like Ascorbic acid with Iron or Copper in Vitro. In our study the effect of oxidative stress on RBC membrane in diabetes was estimated and the same was validated by subjecting Erythrocyte membranes of controls to oxidative stress in vitro by using Ascorbic acid with Iron.

A case control comparative study was done with type $2 \mathrm{DM}$ patient blood samples and normal controls at BMCH \& RC, Chitradurga. The maximum number were of the age group of 41- 45 i.e. 32\%. The mean FBS levels among cases and controls $197.50 \mathrm{mg} / \mathrm{dl}$ and $93.48 \mathrm{mg} / \mathrm{dl}$ respectively. There was similarity in the results between levels of protein content (4.56 \pm 0.19$)$, protein carbonyl (1.20 \pm 0.08$)$, protein thiol levels $(1.42 \pm 0.10)$ and MDA $(4.23 \pm 0.21)$ among diabetics in comparison to protein content (4.28 \pm 0.14$)$, protein carbonyl (1.39 $\pm .0 .097)$, protein thiols $(1.04 \pm 0.05)$ and MDA (4.75 \pm 0.81$)$ in controls treated with Iron Ascorbate a pro-oxidant mixture.
\end{abstract}

Keywords: Diabetes mellitus, Reactive oxygen species, Protein content, Protein carbonyl, Protein thiols, Iron ascorbate.

\section{Introduction}

Type 2 diabetes mellitus (DM) is a chronic endocrine disorder in which prevalence has been escalating steadily all over the world. As a result of this trend, it is rapidly becoming an epidemic in many regions of the world with the number of people affected expected to double in the next decade due to increase in ageing population, thereby adding to the already existing burden for healthcare providers, especially in poorly developed countries. People afflicted with type 2 $\mathrm{DM}$ are more prone to various forms of both short- and long-term complications, which often lead to their reduced life span. This tendency of increased morbidity and mortality is seen in patients with type $2 \mathrm{DM}$ because of the increased prevalence of this type of DM, its insidious onset and delayed recognition, especially in resource challenged regions like India and Africa. ${ }^{1}$ Type $2 \mathrm{DM}$ is primarily due to lifestyle factors and genetic makeup which in turn leads to an interplay of insulin resistance and insulin defficiency. ${ }^{2}$ Numerous lifestyle factors are known to be important in the development of type 2 DM. These are lack of exercise, sedentary lifestyle, tobacco smoking and excessive consumption of alcohol. ${ }^{3}$

Reactive oxygen species leading to oxidative stress plays a key role in the aetiopathogenesis of persistent and progressively deteriorative diseases such as malignancies, arthritis, senility, autoimmune disorders, cardiovascular and neurodegenerative diseases, diabetes being one among them. Various antioxidants are endogenously synthesized in the human body. They are also obtained exogenously through diet and supplements. These antioxidants act as free radical scavengers by preventing and repairing impairments caused by ROS and RNS, and hence can increase the immune defense and decrease the risk of malignancies, metabolic and degenerative diseases. ${ }^{4}$

The concept of free radicals has been in vogue since the past fifty years; however the past two decades has seen a tremendous increase in the understanding of their roles in the development of diseases, and also of the beneficial effects of antioxidants on health.

Oxidative stress can arise when cells cannot adequately cope up with the excess of free radicals formed. Oxidative stress which occurs due to increased generation of free radicals can damage cell membranes. Free radicals also have deleterious effects on other structures such as proteins, lipids, lipoproteins, and deoxyribonucleic acid. ${ }^{6}$ In other words; oxidative stress results from an imbalance between formation and deactivation of ROS/RNS. Biological free radicals are thus highly unstable entities that have electrons available to react with different organic substrates such as lipids, proteins, DNA. Free radicals can be formed due to non-enzymatic reactions of oxygen with organic compounds as well as those initiated by ionizing radiations. The nonenzymatic process can also occur during oxidative phosphorylation (i.e. aerobic respiration) in the mitochondria. ${ }^{7}$ 
ROS and RNS are produced from either endogenous or exogenous sources. The causative factors implicated in the generation of endogenous free radicals are ischemia, infection, heavy physical exercise, ageing, malignancies and mental stress. Exogenous factors implicated in the generation of ROS/RNS are air and water pollution, radiation, tobacco smoke, alcohol, heavy metals $(\mathrm{Cd}, \mathrm{Hg}, \mathrm{Pb}, \mathrm{Fe}$, As), certain drugs (cyclosporine, tacrolimus, gentamycin, bleomycin), industrial solvents and cooking (smoked meat, used oil, fat). ${ }^{8}$ After entry into the body by various routes, these exogenous compounds are degraded or metabolized into free radicals.

Iron has both beneficial and deleterious effects on the body. In moderate quantities and in protein bound form, it is an essential micro nutrient for growth and for all aerobic metabolic processes, but it is deleterious in unbound free form. Because of its property to alternate between ferrous and ferric states by varying the ligands with which it is associated, Iron can be both a strong biologic oxidant and a reducing agent. ${ }^{9}$

Circulating form of free iron is toxic. There are two iron binding proteins in the human body namely Transferrin and Ferritin. These mop up the free iron and thus prevent the production of free radicals. Transferrin is a high affinity protein which is involved in the transport of free iron, whereas ferritin is involved in the storage of iron. Iron stored in the ferritin molecule is internalized within the shell of the molecule as non toxic $\mathrm{Fe}^{3+}$. In the presence of high levels of reduced ascorbic acid, it enters the ferritin protein shell and is involved in the conversion of $\mathrm{Fe}^{3+}$ to toxic $\mathrm{Fe}^{2+}$ which then escapes out of the ferritin shell leading to production of billions of free radicals. Ferritin protein is an acute phase reactant that increases sharply in the presence of inflammation of any type, whereas transferrin is a reverse acute phase reactant that decreases in the presence of inflammation of any type. ${ }^{10}$

Ascorbic acid (vitamin C) is a water-soluble micronutrient required for multiple biological functions. In a variety of other functions, the role of ascorbic acid in cellular metabolism can be accounted for by its reducing properties to protect cellular components from oxidative damage. ${ }^{11}$

Vitamin C (ascorbic acid (AA) is well known for its antioxidant properties. Consequently, many other multidimensional aspects of this element are underestimated or even overlooked. In the present paper, we have tried to bring to the foreground some of these aspects, including the pro-oxidant property. ${ }^{12}$

Pro-oxidant effect of Vitamin C: Paradoxically, ascorbic acid is also known to act as a pro-oxidant in vitro. Mixtures of ascorbic acid and copper or iron have been used for decades to induce oxidative modifications of lipids, proteins and DNA. ${ }^{13}$ Ascorbic acid may contribute to oxidative damage formation by reducing ferric $\mathrm{Fe} 3+$ to ferrous $\mathrm{Fe} 2+$ ions (and $\mathrm{Cu} 2+$ to $\mathrm{Cu}+$ ), which in turn can reduce hydrogen peroxide ( $\mathrm{H} 2 \mathrm{O} 2)$ to hydroxyl radicals. However, in general these vitamin Cmediated Fenton reactions should be controlled in the human body due to efficient iron sequestration by metal binding proteins such as ferritin and transferrin. Consequently, it has been argued that the proxidant effect may not be relevant in vivo. ${ }^{14}$ Nevertheless, vitamin $\mathrm{C}$ supplements have not been recommended in people with high iron levels or in pathological conditions associated with iron overload such as thallesemia or hemochromatosis. ${ }^{15}$ Indeed, a mechanism has been provided by which vitamin $\mathrm{C}$ induces the decomposition of lipid hydro peroxides to genotoxic bi functional electrophiles in vitro without the need for free transition metal ions. ${ }^{16}$

Paradoxically, in vitro L-ascorbic acid can also promote the generation of reactive oxygen species $(\mathrm{OH}$, $\mathrm{O} 2-, \mathrm{H} 2 \mathrm{O} 2$, and $\mathrm{Fe} 3+$ ion) in the presence of free $\mathrm{Fe} 3+$ or $\mathrm{Cu} 2+$. This pro-oxidant activity derives from the ability of L-ascorbic acid to reduce $\mathrm{Fe} 3+$ or $\mathrm{Cu} 2+$ to $\mathrm{Fe} 2+$ or $\mathrm{Cu}+$, respectively, and to reduce $\mathrm{O} 2$ to $\mathrm{O} 2$ and $\mathrm{H} 2 \mathrm{O} 2 .{ }^{17}$ However, after summarizing the results of in vivo studies that assessed the oxidation of LDL, lipids and proteins, no pro-oxidant activity contributed to $\mathrm{L}$ - ascorbic acid was evident. ${ }^{18}$

$\mathrm{L}$-ascorbic acid reduces $\mathrm{Fe} 3+$ to $\mathrm{Fe} 2+$ from nonheme iron sources and thus enhances iron absorption. ${ }^{19}$ In the presence of redox-active iron, L-ascorbic acid acts as a pro-oxidant in vitro and might contribute to the formation of hydroxyl radicals, which eventually may lead to lipid, DNA or protein oxidation. ${ }^{20}$

\section{Materials and Methods}

The study was conducted in the department of Biochemistry and department of Internal Medicine, BMCH and RC Chitradurga from January 2013 to December 2014. After taking due clearance from the Ethics committee; a written informed consent was obtained from all participants in this study. A total of 100 patients with type 2 diabetes mellitus were selected from the institute's Internal Medicine department. The diagnosis of type 2 diabetes mellitus was confirmed by glycosylated hemoglobin (>7). Hundred age and sex matched apparently healthy individuals with normal plasma glucose and with no symptoms suggestive of diabetes mellitus were taken as controls. Fasting plasma glucose was determined by using commercially available reagents in automated analyzer ${ }^{21}$ The estimation of glycosylated hemoglobin was done by cation exchange resin method, RBC membrane were prepared by Dodge et al, ${ }^{22}$ protein content by Lowry et $\mathrm{al},{ }^{23}$ protein carbonyl estimation was done by Levine et $\mathrm{al}^{24}$ method and protein thiols by Habeeb AFSA Method. ${ }^{25}$

Data from both groups were tabulated in Microsoft Excel 2007 and statistical analysis of data was performed using SPSS (Version 20.0). Chi-square and Fisher Exact test has been used to find the significance 
of protein, protein carbonyl and protein thiols between cases and controls.

\section{Results}

The random serum glucose, glycated hemoglobin, the RBC membrane protein content, protein carbonyl content, protein thiols and MDA were estimated in all type 2 DM cases and controls treated with iron ascorbate (proxidant) in vitro.

Results showed that the mean levels of protein content, protein thiols were decreased; protein carbonyl and MDA were increased in type 2 DM cases in comparison with controls.

There was similarity in the results between levels of protein content $(4.56 \pm 0.19)$, protein carbonyl $(1.20 \pm 0.08)$, protein thiol levels $(1.42 \pm 0.10)$ and MDA $(4.23 \pm 0.21)$ among diabetics in comparison to protein

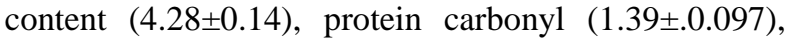
protein thiols $(1.04 \pm 0.05)$ and MDA $(4.75 \pm 0.81)$ in controls treated with Iron Ascorbate a pro-oxidant mixture.

Table 1: Comparison of study variables in type 2 diabetic cases and control with controls with iron ascorbate

\begin{tabular}{|l|c|c|c|c|}
\hline \multicolumn{1}{|c|}{ Variables } & Controls & Cases & $\begin{array}{c}\text { Controls with Iron } \\
\text { Ascorbate }\end{array}$ & P value \\
\hline PROTEIN (mg/ml) & $5.40 \pm 0.31$ & $4.56 \pm 0.19$ & $4.28 \pm 0.14$ & $<0.001^{* *}$ \\
\hline $\begin{array}{l}\text { PROTEIN CARBONYL (nmols } \\
\text { /mg of protein) }\end{array}$ & $0.90 \pm 0.06$ & $1.20 \pm 0.08$ & $1.39 \pm .0 .097$ & $<0.001^{* *}$ \\
\hline $\begin{array}{l}\text { PROTEIN THIOLS } \\
\text { (nmols /mg of protein) }\end{array}$ & $2.12 \pm 0.12$ & $1.42 \pm 0.10$ & $1.04 \pm 0.05$ & $<0.001^{* *}$ \\
\hline MDA & $3.28 \pm 0.19$ & $4.23 \pm 0.21$ & $4.75 \pm 0.81$ & $<0.001^{* *}$ \\
\hline
\end{tabular}

Significantly more with $\mathrm{P}=<0.001 * *$

\section{Discussion}

Definitive evidence suggest that free radicals are linked to oxidative stress and are involved in the aetiopathogenesis of severe disorders such as diabetic retinopathy, diabetic nephropathy bronchopulmonary dysplasia, intraventricular hemorrhage, and hypoxicischemic encephalopathy. ${ }^{26}$

In these oxidative stress-related pathologies, iron is release from iron stores and may cause cell damage by lipid and protein peroxidation. ${ }^{27}$ Heavy metals $(\mathrm{Cd}, \mathrm{Hg}$, $\mathrm{Pb}, \mathrm{As}$ ) and transition metals ( $\mathrm{Fe}, \mathrm{Cu}, \mathrm{Co}, \mathrm{Cr}$ ) are involved in the aetiopathogenesis of nephropathy and carcinogenicity by inducing generation of significant quantities of free radicals. ${ }^{28,29}$

Ascorbic acid normally reduces free toxic iron, which can auto-oxidize to produce superoxide, but may promote lipid peroxidation when the concentration is insufficient to keep all the iron reduced. Ascorbate plays an important role in protecting cells against oxidative stress. Paradoxically, in the presence of $\mathrm{Fe}^{3+}$ or $\mathrm{Cu}^{2+}$, ascorbate can trigger the production of the same reactive oxygen species $\left(\mathrm{OH}, \mathrm{O}_{2}-, \mathrm{H}_{2} \mathrm{O}_{2}\right.$, and ferrous ion) it is known to destroy. The ability of ascorbate to reduce $\mathrm{Fe}^{3+}$ or $\mathrm{Cu}^{2+}$ to $\mathrm{Fe}^{2+}$ or $\mathrm{Cu}^{+}$, respectively, and to reduce $\mathrm{O}_{2}$ to $\mathrm{O}_{2}-$ and $\mathrm{H}_{2} \mathrm{O}_{2}$ accounts for its pro oxidant property. ${ }^{30}$

\section{Conclusion}

The present study suggested excess free radicals are generated due to hyperglycemia and its associated metabolic syndromes, it is also seen that similar results are observed when a combination of iron-ascorbate (pro-oxidant) is used. Therefore our study validates the membrane damage caused by free radicals in vivo due to diabetes mellitus and similar results when $\mathrm{RBC}$ membranes are treated with pro-oxidant in vitro.

\section{References}

1. Azevedo M, Alla S. Diabetes in sub-Saharan Africa: Kenya, Mali, Mozambique, Nigeria, South Africa and Zambia. Int J Diabetes Dev Ctries. 2008;28(4):101-108.

2. Ripsin CM, Kang H, Urban RJ. Management of blood glucose in type 2 diabetes mellitus. Am Fam Physician. 2009;79(1):29-36.

3. Hu FB, Manson JE, Stampfer MJ, Colditz G, Liu S, Solomon CG, et al. Diet, lifestyle, and the risk of type 2 diabetes mellitus in women. $N$ Engl $J$ Med. 2001;345(11):790-797.

4. Valko M, Rhodes CJ, Moncol J, Izakovic M. Free radicals, metals and antioxidants in oxidative stressinduced cancer. Mini-review. Chem Biol Interact. 2006;160:1-40.

5. Valko M, Leibfritz D, Moncola J, Cronin MD. Free radicals and antioxidants in normal physiological functions and human disease. Review. Int J Biochem Cell Biol. 2007:39:44-84.

6. Droge W. Free radicals in the physiological control of cell function. Review. Physiol Rev. 2002;82:47-95.

7. Valko M, Leibfritz D, Moncola J, Cronin MD. Free radicals and antioxidants in normal physiological functions and human disease. Review. Int J Biochem Cell Biol. 2007;39:44-84.

8. Halliwell B. Biochemistry of oxidative stress. Biochem Soc Trans. 2007;35:1147-1150.

9. Giuseppe Buonocore and Serafina Perrone, Iron: A Potent Pro-Vol. 47 Supplement. Nestec Ltd., Vevey/Lippincot Williams \& Wilkins, Philadelphia (C) 2002.oxidant

10. Herbert V, Shaw S, Jayatilleke E. Vitamin C-driven free radical generation from iron. $J$ Nutr. 1996;126(7):1902.

11. Sailaja Rao P, Sireesha Kalva, Aparna Yerramilli, Sadanandam Mamidi. Free Radicals and Tissue Damage: Role of Antioxidants. 2011;1(4).

12. Arrigoni O, De Tullio MC. Ascorbic acid: much more than an antioxidant. Biochem Biophys Acta. 2002;1569(13):1-9. 
13. Duarte, T.L., Lunec, J., "Review: When is an antioxidant not an antioxidant? A review of novel actions and reactions of vitamin C." Free Rad. Res. 2005;39(7):671686.

14. Halliwell B., "Vitamin C: poison, prophylactic or panacea?" Trends Biochem Sci. 1999;24:255-259.

15. Herbert, V., Shaw, S., Jayatilleke, E. "Vitamin C-driven free radical generation from iron" $J$ Nutr. 1996; 126:1213S-1220S

16. Villacorta, L., Azzi, A., Zingg, J.M., "Regulatory role of vitamins $\mathrm{E}$ and $\mathrm{C}$ on extracellular matrix components of the vascular system." Molecular Aspects of Med. 2007; 28:507-537.

17. Carr, A.C., Frei, B., "Does vitamin C act as pro-oxidant under physiological conditions?" FASEB J. 1999;13:1007-1024.

18. Goswami T, Rolfs A, Hediger M. A., "Iron transport: emerging roles in health and disease." Biochem Cell Biol. 2002;80(5):679-689.

19. Samuni, A., Aronovitch, J., Godinger, D., Chevion, M., Czapski, G., On the cytotoxicity of vitamin $\mathrm{C}$ and metal ions. A site-specific Fenton Mechanism." Eur J Biochem., 1983;137(1-2):119-124.

20. Gowenlock AH, Mc Maurray JR, Mc Lauchun DM. Tests in disorders of glucose metabolism. In: Weiner K edn. Practical Clinical Biochemistry. Chapter 25.6 edn. CBS publishers. 1996:333-49.

21. Dodge JT, Mitchell C, Hanahan D J. The preparation and chemical characteristics of hemoglobin free ghosts of human erythrocyte. Arch Biochem Biophys. 1963;100:119-130.

22. Lowry OH, Rosebrough NJ, Farr AL, Randall RJ. Protein measurement with Folin-Phenol reagent. J Biol Chem. 1951;193:265-275.
23. Levine RL, Williams JA, Stadtman ER, Shacter: E. Carbonyl assays for determination of oxidatively modified proteins. Methods Enzymol. 1994;233:346-357.

24. Habeeb A.F.S.A. Reaction of protein sulfhydryl groups with Ellman's reagent. Methods Enzymol. 1972;25:457464.

25. Saugstad OD. Oxygen toxicity in the neonatal period. Ada Pediatr Scand. 1990;79:881-92.

26. Saugstad OD. Mechanisms of tissue injury by oxygen radicals: implications for neonatal disease. Ada Paediatr. 1996;85:1-42.

27. Valko M, Rhodes CJ, Moncol J, Izakovic M. Free radicals, metals and antioxidants in oxidative stressinduced cancer. Mini- review. Chem Biol Interact. 2006;160:1-40.

28. Valko M, Morris H, Cronin MTD. Metals, toxicity and oxidative stress. Curr Med Chem. 2005;12:1161-1208.

29. E R Stadtman. Ascorbic acid and oxidative inactivation of proteins. The American Journal of Clinical Nutrition. 1991;54(6):1125S-1128S

How to cite this article: Afreen A, Javarappa D, Itagappa M. Comparative study of oxidative stress in type 2 diabetes mellitus with in vitro oxidative stress using ferrous ascorbate as prooxidant. Int J Clin Biochem Res. 2018;5(4):551554. 